\section{THERMO-MECHANICAL PROCESSING (TMP) of Ti-48Al-2Nb-2Cr BASED ALLOYS}

\author{
G. E. Fuchs
}

February 1995

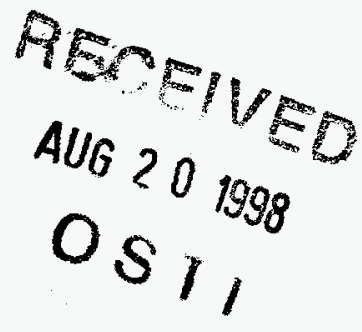

DISTRIBUTION OF THS DOCUMENT IS UMH

\title{
NOTICE
}

This report was prepared as an account of work sponsored by the United States Government. Neither the United States, nor the United States Department of Energy, nor any of their employees, nor any of their contractors, subcontractors, or their employees, makes any warranty, express or implied, or assumes any legal liability or responsibility for the accuracy, completeness or usefulness of any information, apparatus, product or process disclosed, or represents that its use would not infringe privately owned rights.

KAPL ATOMIC POWER LABORATORY

SCHENECTADY, NEW YORK 12301

Operated for the U. S. Department of Energy by KAPL, Inc. a Lockheed Martin company 


\section{DISCLAIMER}

This report was prepared as an account of work sponsored by an agency of the United States Government. Neither the United States Government nor any agency thereof, nor any of their employees, make any warranty, express or implied, or assumes any legal liability or responsibility for the accuracy, completeness, or usefulness of any information, apparatus, product, or process disclosed, or represents that its use would not infringe privately owned rights. Reference herein to any specific commercial product, process, or service by trade name, trademark, manufacturer, or otherwise does not necessarily constitute or imply its endorsement, recommendation, or favoring by the United States Government or any agency thereof. The views and opinions of authors expressed herein do not necessarily state or reflect those of the United States Government or any agency thereof. 


\section{DISCLAIMER}

Portions of this document may be illegible in electronic image products. Images are produced from the best available original document. 


\title{
Thermo-Mechanical Processing (TMP) of Ti-48Al-2Nb-2Cr Based Alloys
}

\author{
G.E. Fuchs \\ KAPL, Inc. \\ Martin Marietta Corporation \\ P.O. Box 1072 \\ Schenectady, NY 12301-1072
}

\begin{abstract}
The effects of heat treatment and deformation processing on the microstructures and properties of $\gamma$-TiAl based alloys produced by ingot metallurgy (I/M) and powder metallurgy $(\mathrm{P} / \mathrm{M})$ techniques were examined. The alloy selected for this work is the second generation $\gamma$ TiAl based alloy - Ti-48Al-2Nb-2Cr (at \%). Homogenization of $\mathrm{I} / \mathrm{M}$ samples was performed at a variety of temperatures, followed by hot working by isothermal forging. P/M samples were prepared from gas atomized powders, consolidated by both HIP and extrusion and some of the HIPed material was then hot worked by isothermal forging. The effects of processing, heat treatment and hot working on the microstructures and properties will be discussed.
\end{abstract}




\section{Introduction}

Alloys based on the intermetallic compound TiAl have attracted a great deal of interest for high temperature structural applications due to their attractive properties (e.g., low density, high temperature strength, oxidation resistance and burn resistance) [1-4]. The vast majority of work exploring the physical and mechanical metallurgy of TiAl-based alloys has utilized materials processed by ingot metallurgy (L/M) processing techniques. A significant amount of alloys have been screened by examining the properties of cast or cast and forged materials. However, only limited work has been performed on a single alloy composition processed by different methods. Preliminary data indicate that powder metallurgy (P/M) processing techniques result in material with superior properties due to the more refined and homogeneous microstructures produced in these materials [5]. The purpose of this study was to evaluate the effect of thermo-mechanical processing, or TMP, on the microstructure and properties of both $\mathrm{I} / \mathrm{M}$ and $\mathrm{P} / \mathrm{M}$ processed $\mathrm{Ti}-48 \mathrm{Al}-2 \mathrm{Nb}-2 \mathrm{Cr}$ alloys.

\section{Experimental Procedures}

Materials with a nominal composition of $\mathrm{Ti}-48 \mathrm{Al}-2 \mathrm{Nb}-2 \mathrm{Cr}$ (at\%) were processed by both $\mathrm{I} / \mathrm{M}$ and $\mathrm{P} / \mathrm{M}$ processing techniques (Table 1 ). The $\mathrm{I} / \mathrm{M}$ samples had a slightly lower Al content than the P/M samples. The I/M materials (ID TA-44) were vacuum induction skull melted at Duriron Company, Dayton, Ohio. The TA-44 ingot was cast into a $7 \mathrm{~cm}$ diameter $\times 91 \mathrm{~cm}$ cylindrical graphite mold and $\mathrm{HIPed}\left(1260^{\circ} \mathrm{C} / 172 \mathrm{MPa} / 4 \mathrm{hrs}\right)$ to eliminate any casting porosity. The ingot was cut into forging mults and homogenized at a variety of temperatures prior to forging at Ladish Company, Inc., Cudahy, Wisconsin (Table 2). One of the mults, TA-44AG, was homogenized in the $\alpha+\gamma$ phase field; whereas, the remaining mults were homogenized in the $\alpha$ phase field. Two different temperatures were examined during the single phase homogenization. One mult, TA-44D-G, was homogenized at $1400^{\circ} \mathrm{C}$ for 5 hours. The remaining mults, TA-44J-G, TA-44JB-A and TA-44JB-G, were homogenized at $1440^{\circ} \mathrm{C}$ for 20 minutes. All of the mults, except the TA-44JB-A and the TA-44JB-G samples, were isothermally forged in one-step $\left(1175^{\circ} \mathrm{C} / 75 \% / 0.1 \mathrm{~min}^{-1}\right)$. The TA-44JB-A and the TA-44JB-G mults were forged in two-steps. The initial ingot breakdown was performed $\left(1175^{\circ} \mathrm{C} / 50 \% / 0.1 \mathrm{~min}^{-1}\right)$ followed by a recrystallization heat treatment $\left(1200^{\circ} \mathrm{C} / 48 \mathrm{hrs}\right)$. The TA-44JB-A and TA-44JB-G mults were then final forged $\left(1175^{\circ} \mathrm{C} / 75 \% / 0.1 \mathrm{~min}^{-1}\right)$.

The P/M samples were produced by gas atomization techniques at Crucible Research Center, Oakdaie, Pennsylvania. Approximately half of the -35 mesh $(<500 \mu \mathrm{m})$ powder yield from a single heat was canned in CP-Ti cans and consolidated by HIPing $\left(1230^{\circ} \mathrm{C} / 172 \mathrm{MPa} / 4 \mathrm{hrs}\right)$. A portion of the HIP consolidated material was isothermally forged in the temperature range $1100^{\circ}-1175^{\circ} \mathrm{C}$ at strain ranges including $0.1-0.3 \mathrm{~min}^{-1}$ (Table 2). The remaining powder yield was canned in CP-Ti cans, wrapped in Ta foil and canned again in mild steel extrusion cans and consolidated $\left(1300^{\circ} \mathrm{C} / 16: 1\right)$.

A limited amount of both the $\mathrm{I} / \mathrm{M}$ and $\mathrm{P} / \mathrm{M}$ processed materials were given heat treatment 
to produce the duplex microstructure (HT A: $1300^{\circ} \mathrm{C} / 2 \mathrm{hrs} / \mathrm{AC}+900^{\circ} \mathrm{C} / 6 \mathrm{hrs} / \mathrm{AC}$ ). However, the majority of the I/M and P/M samples were given a heat treatment to produce the near-lamellar microstructure. Due to the difference in $\mathrm{Al}$ contents in the $\mathrm{I} / \mathrm{M}$ and $\mathrm{P} / \mathrm{M}$ samples (Table 1), the heat treatment temperatures were adjusted to produce a high volume fraction of $\alpha_{2} / \gamma$ lamellar grains. The I/M samples were given a $1330^{\circ} \mathrm{C} / 2 \mathrm{hrs} / \mathrm{AC}+900^{\circ} \mathrm{C} / 6 \mathrm{hrs} / \mathrm{AC}$ heat treatment (HT G). A $1350^{\circ} \mathrm{C} / 2 \mathrm{hrs} / \mathrm{AC}+900^{\circ} \mathrm{C} / 6 \mathrm{hrs} / \mathrm{AC}$ (HT L) heat treatment was utilized for the $\mathrm{P} / \mathrm{M}$ samples to produce the near-lamellar microstructure.

Metallographic samples were examined by optical metallography, scanning electron microscopy (SEM) and transmission electron microscopy (TEM). Threaded tensile and creep samples with a $3.81 \mathrm{~mm}$ diameter $\times 1.27 \mathrm{~cm}$ gage section were tested in air. The tensile samples were tested at $25^{\circ}, 600^{\circ}$ and $850^{\circ} \mathrm{C}$ at an initial strain rate of $0.1 / \mathrm{min}$. The constant load creep samples were tested at $850^{\circ} \mathrm{C}$ at an initial stress of $103 \mathrm{MPa}$ (Duplex samples) or $138 \mathrm{MPa}$ (Near-lamellar samples). The fractured samples were then examined by SEM and TEM to determine the fracture mechanisms.

$\underline{\text { Results and Discussion }}$

\section{Microstructures}

When heat treated to a duplex microstructure, both the I/M and the P/M samples exhibited a fine equiaxed microstructure (Table 2). All of the samples exhibited a mixture of fine single phase $\gamma$ grains, $\alpha_{2} / \gamma$ lamellar grains and very fine equiaxed single phase $\alpha_{2}$ grains at grain boundary triple points. Some limited amount of ordered $\beta-\mathrm{Ti}_{2} \mathrm{AlCr}$ was observed in all of the alloys. The I/M sample (TA-44JB-A) exhibited the finest grain size and the P/M HIP + forged sample (TA-80A) exhibited the coarsest grain size. The P/M HIP (TA-47A) and the P/M extruded (TA-50A) samples exhibited an intermediate grain size.

Significant differences in the near-lamellar microstructures were observed (Table 2 and Figure 1). In all cases a near-lamellar microstructure, characterized by a high volume fraction of $\alpha_{2} / \gamma$ lamellar grains, were produced by the heat treatments. The I/M samples exhibited coarse microstructures with the final grain size dependent on the homogenization and the hot working history. The sample homogenized in the two phase $(\alpha+\gamma)$ field (TA-44A-G), exhibited an inhomogeneous microstructure without a uniform grain size. This heterogeneous microstructure is probably due to the incomplete homogenization attained by the initial homogenization heat treatment in the two phase field [6]. Homogenization in the single phase, $\alpha$-phase, field did produce a uniform microstructure. Two-step forging resulted in significant grain refinement in the near-lamellar samples. The P/M HIP (TA-47L) and P/M extrude (TA-50L) exhibited much finer grain size than the I/M samples and isothermal forging of the HIPed material appeared to result in coarser grain sizes in the heat treated condition. Decreasing the forging temperature and/or increasing the forging strain rate did appear to refine the microstructure. 


\section{Tensile Properties}

Room temperature: Generally higher strengths and greater ductilities were observed in the samples with duplex microstructures when tested at room temperature (Table 3). The high strength of the duplex samples is probably due to the finer, more homogeneous microstructures. The two-step forged I/M material (TA-44JB-A) exhibited the highest strength, probably due to the lower Al content and more extensive hot working. Although all of the P/M samples exhibited lower strength than the I/M samples, the P/M HIP+forge samples (TA-80A) exhibited the highest ductility. The high level of ductility may be due to the more homogeneous, refined microstructure observed in the P/M samples.

The near-lamellar I/M samples (Table 3) exhibited lower strength and lower ductility than the duplex samples. Increasing the homogenization temperature in the $\alpha$-phase field did appear to increase the strength of the I/M samples. Although the two-step forging (TA-44JB-G) did not appear to significantly change the strength of the $\mathrm{I} / \mathrm{M}$ materials, it did seem to increase the ductility. Homogenization of the samples in the $\alpha+\gamma$ phase field (TA-44A-G) resulted in a material with moderate strength and ductility. The P/M HIP (TA-47L) and the P/M extruded (TA-50L) samples exhibited slightly higher strengths and ductilities when heat treated to form a near-lamellar microstructure. In fact, the P/M HIP and the P/M extruded samples exhibited the highest ductility of any of the near-lamellar samples studied. In general, the P/M samples exhibited lower strengths and higher ductilities than the I/M samples. The P/M extruded samples (TA-50L) exhibited the highest strength and ductility of the P/M samples. Forging did not appear to affect the strength, but did decrease the ductility of the P/M HIP material. Decreasing the forging temperature and increasing the forging strain rate did increase the ductility of the $P / M$ HIP+forge samples.

$600^{\circ} \mathrm{C}$ : Increasing the test temperature to $600^{\circ} \mathrm{C}$ (Table 3) resulted in a greater decrease in strength in the duplex I/M samples than the duplex P/M samples. The I/M samples still exhibited higher strength, but now also exhibited greater ductility than the P/M samples. Among the P/M samples, the P/M HIP+forge (TA-80A) material exhibited the highest strength, but the P/M extruded samples exhibited the highest ductility. Forging of the P/M-HIP+forged sample appeared to result in increased strength and ductility.

When heat treated to a near-lamellar microstructure (Table 3), the I/M samples exhibited less of a decrease in strength with increasing test temperature than the $\mathrm{P} / \mathrm{M}$ samples. The highest strength was observed in the $\mathrm{I} / \mathrm{M}$ sample homogenized in the $\alpha+\gamma$ phase field (TA-44A-G). The lowest strength, but highest ductility was observed in the $\mathrm{I} / \mathrm{M}$ samples homogenized at $1400^{\circ} \mathrm{C}$ (TA-44D-G). Two-step forging of the I/M alloy (TA-44JB-G) appeared to result in slightly decreased strength, but increased ductility. The highest strength and ductility observed in the $\mathrm{P} / \mathrm{M}$ samples was obtained in the P/M extruded samples (TA-50L). Forging of the P/M samples appeared to slightly decrease the strength and slightly increase the ductility of the P/M HIP material.

$850^{\circ} \mathrm{C}$ : When the test temperature was increased to $850^{\circ} \mathrm{C}$ (Table 3), the $\mathrm{I} / \mathrm{M}$ duplex and the 
$\mathrm{P} / \mathrm{M}$ HIP+forge samples exhibited a decrease in strength. However, an increase in strength was observed in the P/M HIP (TA-47A) and P/M extruded (TA-50A) samples. In all cases, the increased test temperature resulted in increased ductility. The highest strength was observed in the P/M extrude samples, but the P/M HIP+forge samples exhibited the highest ductility. Forging of the P/M HIIP material resulted in increased strength and ductility.

Increasing the test temperature to $850^{\circ} \mathrm{C}$ for the near-lamellar samples (Table 3) resulted in an anomalous increase in the strength for the P/M samples. However, a clear trend in the $I / M$ samples was not observed. The highest strengths were observed in the one-step forged $I / M$ samples homogenized at $1400^{\circ} \mathrm{C}$ (TA-44D-G) and the P/M HIIP samples (TA-47L) exhibited the greatest ductility. The P/M extruded material (TA-50L) exhibited the best balance of properties with moderately high strength and ductility. Two-step forging of the I/M samples did not have a significant effect on the tensile properties. Forging of the P/M samples did not result in any significant change in tensile strength, but did result in reduced ductility.

\section{Creep Properties}

The constant load creep properties of the duplex materials was evaluated at $850^{\circ} \mathrm{C}$ in air at an initial stress of $103 \mathrm{MPa}$ (Table 4). The two-step forged I/M material (TA-44JB-A) exhibited the highest creep resistance. The P/M HIP (TA-47A) and P/M extruded (TA-50A) samples exhibited similar creep resistance, but were slightly inferior to the I/M material. Forging of the P/M HIP material (TA-80A) resulted in a decrease in creep strength.

The constant load creep resistance of the near-lamellar materials were also tested at $850^{\circ} \mathrm{C}$ at an initial stress of $138 \mathrm{MPa}$ (Table 4). The I/M samples exhibited the highest creep resistance. In particular, the samples homogenized at $1440^{\circ} \mathrm{C}$ exhibited the greatest creep strength. The twostep forging process did appear to slightly decrease the creep resistance of the I/M samples. The lowest creep strength was observed in the P/M HIP (TA-47L) sample. Forging of the P/M HIP materials did improve the creep strength and, in particular, decreasing the forging temperature and increasing the forging strain rate resulted in further creep resistance improvements. The creep resistance of the $\mathrm{P} / \mathrm{M}$ extrude material was slightly inferior to the $\mathrm{P} / \mathrm{M}$ HIP+forge material. In general, although the creep resistance of the P/M samples was slightly less than the $\mathrm{I} / \mathrm{M}$ samples, the P/M material exhibited greater creep ductility.

\section{$\underline{\text { Summary }}$}

Homogenization of I/M materials in the single phase ( $\alpha$ ) field prior to hot working results in improved mechanical properties. In addition, two-step forging, instead of one-step forging, further improves the properties of $\mathrm{I} / \mathrm{M}$ samples. The primary reasons for the property improvements observed in the $\mathrm{I} / \mathrm{M}$ materials after high temperature homogenization and two-step forging appeared to increase the chemical and microstructural homogeneity and refined microstructures. 
Hot working of $\mathrm{P} / \mathrm{M}$ materials, either by forging or extrusion, results in materials with increased tensile and creep properties. Decreasing the forging temperature and increasing the forging strain rate resulted in further improvements in properties.

The P/M materials exhibited a better balance of tensile and creep properties than the I/M materials. In particular, the HIP+forged materials, forged at the lower temperatures $\left(1100^{\circ}\right.$ $1150^{\circ} \mathrm{C}$ ) and the extruded material exhibited the best combination of properties.

\section{Acknowledgements}

This work was performed at the Knolls Atomic Power Laboratory, operated for the U.S. Department of Energy by KAPL, Inc., Martin Marietta Corporation, under contract DE-AC12$76 S N 0052$.

\section{$\underline{\text { References }}$}

1.) H.A. Lipsitt, Proc. Mat. Res. Soc., 3, pp 351-364 (1984).

2.) Y.W. Kim, JOM, 41, pp. 24-30 (1989).

3.) Y.W. Kim and D.M. Dimiduk, JOM, 43 , pp. 40-47 (1991).

4.) Y.W. Kim, JOM, 46, pp. 30-40 (1994).

5.) G.E. Fuchs, Proc. Mat. Res. Soc., 288, pp. 847-852 (1993).

6.) G.E. Fuchs, Proc. Int'l Symposium on Structural Intermetallics, Eds., R. Darolia, J.J. Lewandowski, C.T. Liu, P.L. Martin, D.B. Miracle and M.V. Nathal, pp. 195-203 (1993), Warrendale, PA, TMS-AIME. 
Table 1

Composition of $\mathrm{I} / \mathrm{M}$ and $\mathrm{P} / \mathrm{M}$ Ti-48Al-2Nb-2Cr Samples

\begin{tabular}{|c|c|c|c|c|c|c|c|c|c|}
\hline \multirow{3}{*}{$\frac{\text { Processing }^{(1)}}{I / M}$} & \multirow{2}{*}{$\begin{array}{l}\text { Alpha } \\
\text { Transus }\end{array}$} & \multicolumn{4}{|c|}{ Composition (at $\%$ ) } & \multicolumn{4}{|c|}{ Composition (wt\%) } \\
\hline & & $\mathrm{Ti}$ & $\mathrm{Al}$ & $\mathrm{Nb}$ & $\mathrm{Cr}_{\mathrm{T}}$ & $\mathrm{O}_{2}$ & $\mathrm{H}_{2}$ & $\mathrm{~N}_{2}$ & $\mathrm{C}$ \\
\hline & $1343^{\circ} \mathrm{C}$ & bal & 46.48 & 2.07 & 2.03 & 590 & 16 & 82 & 170 \\
\hline $\mathrm{P} / \mathrm{I}$ & $1366^{\circ} \mathrm{C}$ & bal & 47.73 & 1.77 & 1.99 & 560 & 16 & 20 & 100 \\
\hline
\end{tabular}

Note:

(1) Processing I/M: TA-44JB-A, TA-44A-G, TA-44D-G, TA-44J-G, TA-44JB-G

P/M: TA-47A, TA-50A, TA-80A, TA-47L, TA-50L, TA-80L, TA-135L, TA-138L, TA-141L 


\section{Table 2}

Processing History and Grain Size of I/M and P/M Ti-48Al-2Nb-2Cr Samples

Alloy ID

TA-44JB-A

TA-47A

TA-50A

TA-80A

$\frac{\text { Processing History }}{\mathrm{I} / \mathrm{M}-1440^{\circ} \mathrm{C} / 20 \mathrm{~min}+2 \text {-step Forge }\left(1175^{\circ} \mathrm{C} / 0.1 \mathrm{~min}^{-1} / 50 \%+12\right.}$

Grain

A $\left.1 \mathrm{~min}^{-1} / 50 \%+1200^{\circ} \mathrm{C} / 48 \mathrm{hrs}+1175^{\circ} \mathrm{C} / 0.1 \mathrm{~min}^{-1} / 75 \%\right)+\mathrm{HT} \mathrm{A}$

Size $(\mu \mathrm{m})$

$\mathrm{P} / \mathrm{M}-\mathrm{HIP}\left(1230^{\circ} \mathrm{C} / 172 \mathrm{MPa} / 4 \mathrm{hrs}\right)+\mathrm{HT}$ A

$\mathrm{P} / \mathrm{M}$-Extrude $\left(1300^{\circ} \mathrm{C} / 16: 1\right)+\mathrm{HT}$ A

16

$\mathrm{P} / \mathrm{M}-\mathrm{HIP}\left(1230^{\circ} \mathrm{C} / 172 \mathrm{MPa} / 4 \mathrm{hrs}\right)+$ Forge $\left(1175^{\circ} \mathrm{C} / 0.1 \mathrm{~min}^{-1} / 75 \%\right)+\mathrm{HT} \mathrm{A}$

TA-44A-G $\quad \mathrm{I} / \mathrm{M}-1200^{\circ} \mathrm{C} / 96 \mathrm{hrs}+$ Forge $\left(1175^{\circ} \mathrm{C} / 0.1 \mathrm{~min}^{-1} / 75 \%\right)+\mathrm{HT} \mathrm{G}$

TA-44D-G I/M- $1400^{\circ} \mathrm{C} / 5 \mathrm{hrs}+$ Forge $\left(1175^{\circ} \mathrm{C} / 0.1 \mathrm{~min}^{-1} / 75 \%\right)+\mathrm{HT} \mathrm{G}$

TA-44J-G $\quad \mathrm{I} / \mathrm{M}-1440^{\circ} \mathrm{C} / 20 \mathrm{~min}+$ Forge $\left(1175^{\circ} \mathrm{C} / 0.1 \mathrm{~min}^{-1} / 75 \%\right)+\mathrm{HT} \mathrm{G}$

TA-44JB-G

$\mathrm{I} / \mathrm{M}-1440^{\circ} \mathrm{C} / 20 \mathrm{~min}+2$-step Forge $\left(1175^{\circ} \mathrm{C} / 0.1 \mathrm{~min}^{-1} / 50 \%+1200^{\circ} \mathrm{C} / 48 \mathrm{hrs}+1175^{\circ} \mathrm{C} / 0.1 \mathrm{~min}^{-1} / 75 \%\right)+\mathrm{HT} \mathrm{G}$

TA-47L

$\mathrm{P} / \mathrm{M}-\mathrm{HIP}\left(1230^{\circ} \mathrm{C} / 172 \mathrm{MPa} / 4 \mathrm{hrs}\right)+\mathrm{HT} \mathrm{L}$

TA-50L P/M-Extrude $\left(1300^{\circ} \mathrm{C} / 16: 1\right)+\mathrm{HT} \mathrm{L}$

TA-80L

P/M-HIP $\left(1230^{\circ} \mathrm{C} / 172 \mathrm{MPa} / 4 \mathrm{hrs}\right)+$ Forge $\left(1175^{\circ} \mathrm{C} / 0.1 \mathrm{~min}^{-1} / 75 \%\right)+\mathrm{HT} \mathrm{L}$

TA-135L $\mathrm{P} / \mathrm{M}$-HIP $\left(1230^{\circ} \mathrm{C} / 172 \mathrm{MPa} / 4 \mathrm{hrs}\right)+$ Forge $\left(1175^{\circ} \mathrm{C} / 0.3 \mathrm{~min}^{-1} / 75 \%\right)+\mathrm{HT} \mathrm{L}$

TA-138L

P/M-HIP $\left(1230^{\circ} \mathrm{C} / 172 \mathrm{MPa} / 4 \mathrm{hrs}\right)+$ Forge $\left(1150^{\circ} \mathrm{C} / 0.1 \mathrm{~min}^{-1} / 75 \%\right)+\mathrm{HT} \mathrm{L}$

TA-141L $\mathrm{P} / \mathrm{M}$-HIP $\left(1230^{\circ} \mathrm{C} / 172 \mathrm{MPa} / 4 \mathrm{hrs}\right)+$ Forge $\left(1100^{\circ} \mathrm{C} / 0.1 \mathrm{~min}^{-1} / 75 \%\right)+\mathrm{HT} \mathrm{L}$

Heat Treatments:

HT A - Duplex Heat Treatment $-1300^{\circ} \mathrm{C} / 2 \mathrm{hrs} / \mathrm{AC}+900^{\circ} \mathrm{C} / 6 \mathrm{hrs} / \mathrm{AC}$

HT G - Near-Lamellar Heat Treatment $(\mathrm{I} / \mathrm{M})-1330^{\circ} \mathrm{C} / 2 \mathrm{hrs} / \mathrm{AC}+900^{\circ} \mathrm{C} / 6 \mathrm{hrs} / \mathrm{AC}$

HT L - Near-Lamellar Heat Treatment $(\mathrm{P} / \mathrm{M})-1350^{\circ} \mathrm{C} / 2 \mathrm{hrs} / \mathrm{AC}+900^{\circ} \mathrm{C} / 6 \mathrm{hrs} / \mathrm{AC}$ 
Table 3

Tensile Properties of $\mathrm{I} / \mathrm{M}$ and $\mathrm{P} / \mathrm{M}$ Ti-48Al-2Nb-2Cr Samples

Units: YS and UTS - MPa

Tensile Test Temperature

\begin{tabular}{|c|c|c|c|c|c|c|c|c|c|c|}
\hline \multirow[b]{2}{*}{ Alloy ID } & \multirow[b]{2}{*}{ Microstructure } & \multicolumn{3}{|c|}{$25^{\circ} \mathrm{C}$} & \multicolumn{3}{|c|}{$600^{\circ} \mathrm{C}$} & \multicolumn{3}{|c|}{$850^{\circ} \mathrm{C}$} \\
\hline & & YS & UTS & $e_{\ell}$ & YS & UTS & $e_{f}$ & YS & UTS & $\underline{e_{f}}$ \\
\hline TA-44JB-A & Duplex & 495 & 656 & $2.8 \%$ & 420 & 663 & $6.4 \%$ & 370 & 493 & $77.5 \%$ \\
\hline TA-47A & Duplex & 370 & 452 & $2.8 \%$ & 316 & 451 & $3.6 \%$ & 323 & 401 & $36.7 \%$ \\
\hline TA-50A & Duplex & 383 & 497 & $2.1 \%$ & 331 & 506 & $5.1 \%$ & 335 & 425 & $61.5 \%$ \\
\hline TA-80A & Duplex & 406 & 505 & $3.2 \%$ & 359 & 518 & $4.0 \%$ & 339 & 408 & $85.2 \%$ \\
\hline TA-44A-G & Near-lamellar & 429 & 474 & $1.6 \%$ & 394 & 426 & $4.0 \%$ & 401 & 562 & $3.6 \%$ \\
\hline TA-44D-G & Near-lamellar & 393 & 393 & $1.8 \%$ & 326 & 374 & $5.6 \%$ & 404 & 494 & $3.0 \%$ \\
\hline TA-44J-G & Near-lamellar & 469 & 486 & $1.0 \%$ & 353 & 442 & $4.4 \%$ & 343 & 449 & $3.4 \%$ \\
\hline TA-44JB-G & Near-lamellar & 462 & 486 & $1.4 \%$ & 366 & 443 & $2.6 \%$ & 334 & 463 & $4.0 \%$ \\
\hline TA-47L & Near-lamellar & 377 & 497 & $2.9 \%$ & 317 & 474 & $3.6 \%$ & 325 & 431 & $67.1 \%$ \\
\hline TA-50L & Near-lamellar & 446 & 549 & $2.9 \%$ & 383 & 570 & $5.2 \%$ & 395 & 503 & $38.3 \%$ \\
\hline TA-80L & Near-lamellar & 380 & 433 & $1.6 \%$ & 288 & 394 & $3.8 \%$ & 295 & 459 & $10.4 \%$ \\
\hline TA-135L & Near-lamellar & 377 & 435 & $1.8 \%$ & 291 & 398 & $4.0 \%$ & 308 & 416 & $4.2 \%$ \\
\hline TA-138L & Near-lamellar & 372 & 428 & $1.8 \%$ & 301 & 409 & $3.8 \%$ & 344 & 434 & $3.0 \%$ \\
\hline TA-141L & Near-lamellar & 380 & 440 & $2.2 \%$ & 309 & 395 & $4.0 \%$ & 317 & 410 & $4.2 \%$ \\
\hline
\end{tabular}


Table 4

Creep Properties of $\mathrm{I} / \mathrm{M}$ and $\mathrm{P} / \mathrm{M}$ Ti-48Al-2Nb-2Cr Samples

\begin{tabular}{|c|c|c|c|c|c|c|}
\hline \multirow[b]{2}{*}{ Alloy ID } & \multirow[b]{2}{*}{ Microstructure } & \multirow[b]{2}{*}{ Stress (MPa) } & \multicolumn{2}{|c|}{ Time to $(\mathrm{hr})$ : } & \multirow{2}{*}{$\begin{array}{l}\text { Rupture } \\
\text { Ductility }\end{array}$} & \multirow{2}{*}{$\begin{array}{c}\text { Creep } \\
\text { Rate }(1 / \mathrm{hr})\end{array}$} \\
\hline & & & $1 \%$ Strain & $\underline{\text { Rupture }}$ & & \\
\hline TA-44JB-A & Duplex & 103 & 7.5 & 71.5 & $80 \%$ & $2.2 \times 10^{-4}$ \\
\hline TA-47A & Duplex & 103 & 3.6 & 44.2 & $55 \%$ & $4.0 \times 10^{-3}$ \\
\hline TA-50A & Duplex & 103 & 3.3 & 50.1 & $86 \%$ & $4.7 \times 10^{-3}$ \\
\hline TA-80A & Duplex & 103 & 0.9 & 18.7 & $80 \%$ & $9.8 \times 10^{-3}$ \\
\hline TA-44A-G & Near-lamellar & 138 & 24.8 & 87.1 & $12 \%$ & $2.2 \times 10^{-4}$ \\
\hline TA-44D-G & Near-lamellar & 138 & 2.4 & 88.2 & $4 \%$ & $1.1 \times 10^{-3}$ \\
\hline TA-44J-G & Near-lamellar & 138 & 22.7 & 196.0 & $18 \%$ & $2.5 \times 10^{-4}$ \\
\hline TA-44JB-G & Near-lamellar & 138 & 22.9 & 165.0 & $10 \%$ & $2.5 \times 10^{-4}$ \\
\hline TA-47L & Near-lamellar & 138 & 1.8 & 34.7 & $35 \%$ & $3.3 \times 10^{-3}$ \\
\hline TA-50L & Near-lamellar & 138 & 7.4 & 108.9 & $22 \%$ & $8.0 \times 10^{-4}$ \\
\hline TA-80L & Near-lamellar & 138 & 5.7 & 67.8 & $20 \%$ & $6.6 \times 10^{-4}$ \\
\hline TA-135L & Near-lamellar & 138 & 7.5 & 113.6 & $20 \%$ & $2.0 \times 10^{-4}$ \\
\hline TA-138L & Near-lamellar & 138 & 5.6 & 109.7 & $20 \%$ & $8.0 \times 10^{-4}$ \\
\hline TA-141L & Near-lamellar & 138 & 5.4 & 144.4 & $12 \%$ & $1.9 \times 10^{-4}$ \\
\hline
\end{tabular}

